\title{
HUBUNGAN KARAKTERISTIK DENGAN RESPON PETANI DALAM PROGRAM PENGEMBANGAN KEDELAI (Kasus pada Program SL-PTT Kedelai di Kabupaten Ciamis)
}

\author{
Oleh: \\ ZULFIKAR NOORMANSYAH \\ Fakultas Pertanian Universitas Galuh Ciamis \\ e-mail: zulfikarnoormansyah@gmail.com \\ DINI ROCHDIANI \\ Departemen Sosial Ekonomi, Fakultas Pertanian, Universitas Padjadjaran \\ e-mail: dini.rochdiani@yahoo.co.id
}

\begin{abstract}
Abstrak
Penelitian ini bertujuan: 1) Mengindentifikasikan karakteristik petani kedelai Program SL-PTT Kedelai di lahan sawah dan darat, 2) Mengindentifikasikan respons petani dalam melaksanakan usahatani kedelai Program SL-PTT Kedelai di lahan sawah dan darat, dan 3) Menganalisis hubungan karakteristik dan respon petani dalam Program SL-PTT Kedelai di lahan sawah dan darat.Objek penelitian ini adalah karakteristik dan respon petani dalam melaksanakan program SL-PTT Kedelai yang mengambil lokasi penelitian di Kabupaten Ciamis. Metode yang digunakan adalah metode survey. Dengan jumlah responden dalam penelitian ini 241 petani kedelai lahan sawah dari 4.256 petani, dan 137 petani kedelai lahan darat dari 2.414 petani dengan menggunakan stratifikasi random sampling. Hasil penelitian menunjukkan : 1) Secara umum karakteristik petani peserta Program SLPTT Kedelai di Kabupaten Ciamis baik lahan sawah maupun lahan darat masuk dalam kategori sedang. Karakteristik petani kategori lahan sempit untuk petani lahan sawah masuk kategori sedang, sedangkan petani lahan darat masuk kategori rendah. Karakteristik petani kategori lahan luas untuk petani lahan sawah masuk kategori tinggi dan petani lahan darat masuk kategori sedang 2) Respons petani peserta Program SL-PTT Kedelai di Kabupaten Ciamis secara umum masuk kategori tinggi. Respon berdasar katebori lahan sempit untuk lahan sawah masuk kategori sedang dan petani lahan darat masuk kategori tinggi. Untuk kategori lahan luas respon petani lahan sawah masuk kategori tinggi dan petani lahan darat masuk kategori sangat tinggi 3) Terdapat hubungan positif antara karakteristik dan respon petani dalam program SL-PTT kedelai di Kabupaten Ciamis. Dengan sifat hubungan semakin tinggi karakteristik petani maka semakin tinggi pula respon petani dalam pelaksanaan program SL-PTT kedelai di Kabupaten Ciamis.
\end{abstract}

Kata kunci: karakteristik, respon, kedelai, sawah, darat

\section{PENDAHULUAN}

Kabupaten Ciamis merupakan salah satu kabupaten di Jawa Barat sebagai penghasil kedelai yang berpontensi dalam pengembangan usahataninya. Selain itu pengembangan usahatani kedelai di Kabupaten Ciamis melalui kebijakan Dinas Pertanian Kabupaten Ciamis dan Dinas Pertanian Tanaman Pangan Provinsi Jawa Barat telah tersentuh dengan pengembangan usahatani kedelai sistem PTT.

Potensi kedelai di Kabupaten Ciamis pada tahun 2010 memiliki luas panen 1.544 hektar dengan produksi sebanyak 2.298 ton atau mencapai produktivitas 1,49 ton per hektar. Pada tahun 2011 Kabupaten Ciamis memiliki luas panen 3.698 hektar dengan produksi sebesar 5.674 ton atau mencapai produktivitas 1,53 ton per hektar. Pada tahun 2011 mengalami peningkatan dilihat dari luas panen, produksi dan produktivitas nya. Pada tahun 2012 luas panen mengalami penurunan yang sangat drastis menjadi 119 hektar demikian pula pada produksi yang dihasilkan menjadi 199 ton. Menurut informasi dari Dinas Pertanian Kabupaten Ciamis, hal ini diakibatkan terjadinya kegagalan panen di beberapa kecamatan sentra kedelai di Kabupaten Ciamis, gagalnya panen ini diakibatkan oleh tingginya curah hujan pada tahun 2012. Namun meskipun demikian pada tahun 2012 bila dilihat dari produktivitas yang diperoleh mengalami peningkatan dari tahuntahun sebelumnya, yaitu menjadi 1,67 ton per hektar (Dinas Pertanian dan Tanaman Pangan 2011, 2012, 2013). 


\section{AIMBAR \\ Agribisnis}

ISSN 2460-4321

Volume $1 ・$ Nomor $2 \cdot$ Januari 2016

Pada tahun 2013 Kabupaten Ciamis melaksanakan program pengembangan SL-PTT kedelai yang disebar ke 8 kecamatan, yaitu Kecamatan Rancah, Kawali, Ciamis,
Sindangkasih, Panjalu, Cihaurbeuti, Cimerak dan Kecamatan Purwodadi. Untuk lebih jelasnya realisasi Program Pengembangan SLPTT Kedelaitahun 2013 di Kabupaten Ciamis.

Tabel 1. Realisasi Program SL-PTT Kedelai Tahun 2013 di Kabupaten Ciamis

\begin{tabular}{|c|c|c|c|c|c|}
\hline \multirow{2}{*}{ No } & \multirow{2}{*}{ Kecamatan } & \multicolumn{3}{|c|}{ Luas Lahan (ha) } & \multirow{2}{*}{$\begin{array}{l}\text { Jumlah Petani } \\
\text { (orang) }\end{array}$} \\
\hline & & Sawah & Darat & Total & \\
\hline 1 & Rancah & 255 & 210 & 465 & 1.323 \\
\hline 2 & Kawali & 130 & 170 & 300 & 669 \\
\hline 3 & Ciamis & 120 & - & 120 & 598 \\
\hline 4 & Sindangkasih & 90 & 90 & 180 & 692 \\
\hline 5 & Panjalu & 120 & - & 120 & 697 \\
\hline 6 & Cihaurbeuti & - & 250 & 250 & 1.152 \\
\hline 7 & Cimerak & - & 150 & 150 & 1.851 \\
\hline 8 & Purwodadi & 310 & - & 310 & 1.539 \\
\hline & Jumlah & 1.025 & 870 & 1.895 & 7.571 \\
\hline
\end{tabular}

Sumber : Dinas Pertanian Tanaman Pangan Kabupaten Ciamis, 2013

Selain faktor iklim keberhasilan penerapan teknologi atau sistem baru sangat dipengaruhi oleh faktor sosial ekonomi petani yang dapat menjadi karakteristik seorang petani. Karakteristik petani kedelai yang merupakan petani kecil dengan keterbatasan-keterbatasan petani, antara lain dalam bentuk permodalan, penguasaan lahan, keterampilan, pengetahuan, aksesibilitas pasar, cenderung berpengaruh terhadap perilaku dalam pengambilan keputusan mengenai usahatani kedelai, yang diterapkan.

Rendahnya karaketristik dan perilaku petani untuk membuka diri terhadap suatu pembaharuan dan atau informasi yang berkaitan dengan unsur pembaharuan dalam usahatani kedelai juga semakin memperburuk, kondisi petani dalam membuat keputusan untuk menolak atau menerima inovasi. Hal ini cenderung bermuara pada rendahnya pendapatan dan keadaan usahatani yang sulit berkembang. Berdasarkan uraian tersebut, maka sangat perlu dilakukan kanjian tentang Respons Petani Kedelai Terhadap Program Pengembangan di Kabupaten Ciamis.

\section{KAJIAN PUSTAKA}

Penelitian ini menggunakan grand theory modernisasi pertanian. Teori modernisasi Harrod Domar (1947), Max Webber (1904), Mc Lelland (1976), Rostow (1956), Inkeles dan Smith (1961)). Teori ini menyatakan bahwa pembangunan adalah hasil dari transformasi masyarakat dari bentuk tradisional menjadi bentuk modern. Adanya proses perubahan nilai budaya tradisional ke budaya modern. Teori Struktural (Prebisch (1950), Baran Frank (1957). Teori ini menyatakan bahwa keterbelakangan di dunia ketiga bukan disebabkan oleh faktor psikologi atau budaya, melainkan oleh lingkungan material manusia yaitu organisasi kemasyarakatan beserta sistem imbalan-imbalan material yang diberikannya. (Budiman, Arif. 2003)

Menurut Roger dan Shoemaker (1981) karakteristik individu adalah bagian dari ciri pribadi dan melekat pada diri seseorang. Karaketristik tersebut mendasari tingkah laku seseorang dalam bekerja, dan dalam situasi lainnya. Selanjutnya Mardikanto (1993) mengemukakan bahwa karakteristik adalah sisfat-sifat yang melekat pada diri seseorang dan berhubungan dengan aspek kehidupan seperti umur, jenis kelamin, posisi, jabatan, status sosial dan agama.

Lionberger (1960) mengemukakan bahwa karakteristik individu atau personal faktor yang berhubungan dengan semua aspek kehidupan dan lingkungan adalah umur, pendidikan dan karekterisitk psikologis. Karakteristik psikologis ini adalah rasionalitas, fleksibilitas mental, orientasi pada usahatani sebagai bisnis dan kemudahan menerima inovasi.

Berbagai faktor atau karakteristik yang secara teoritis berkaitan dengan fungsi pembentukan perilaku individu dalam melangsungkan kehidupannya seperti: umur, pendidikan, akses informasi, orientassi nilai 
budaya, motivasi berprestai, akses kelompok atau organisasi, akses pasar dan akses terhadap sumber modal.

\section{METODE PENELITIAN}

\section{Objek, Metode dan Lokasi Penelitian}

Objek dalam penelitian ini adalah karakteristik dan respon petani dalam melaksanakan program SL-PTT kedelai. Metode yang digunakan dalam penelitian ini adalah metode survei. Penelitian dilaksanakan di Kabupaten Ciamis pada tahun 2014.

\section{Operasionalisasi Variabel}

Variabel yang dioperasionalkan dalam penelitian ini adalah sebagai berikut :

1. Karakteristik petani adalah ciri dari sifatsifat yang dimiliki petani yang bisa saja dianggap sebagai ciri yang melekat pada petani itu sendiri. Indikator dari karakteristik petani dalam penelitian ini mengenai umur, pendidikan, lahan, pendapatan keluarga, kekayaan, akses terhadap informasi, akses terhadap organisasi/kelompok sosial dan akses pasar. Karakteristik petani ini dinilai dalam bentuk skor

2. Respon petani dalam usahatani kedelai dalam penelitian ini meliputi pengetahuan, sikap dan keterampilan petani dalam melaksanakan kegiatan yang berkaitan dengan usahatani kedelai. Mulai dari persiapan lahan, penggunaan Varietas Unggul Bersertifikat (VUB), penanaman, pemupukan, penggunaan mulsa jerami, pengairan, pengendalian hama, pengendalian penyakit, panen dan pascapanen. Perilaku petani dinilai dalam bentuk skor

\section{Penarikan Sampel}

Untuk mengetahui ukuran sampel yang digunakan sebagai responden dihitung dengan menggunakan rumus Slovin dalam Riduan (2005) sebagai berikut :

$$
n=\frac{N}{N(d)^{2}+1}
$$

Keterangan :

$\mathrm{ni}=$ Ukuran sampel

$\mathrm{N}=$ Ukuran populasi

$\mathrm{d}^{2}=$ Nilai presisi $95 \%$ atau signifikan 0,05

Berdasarkan data Dinas Pertanian Kabupaten Ciamis dan rumus Slovin maka diketahui jumlah sampel dari masing-masing kecamatan di Kabupaten Ciamis dapat dilihat sebagai berikut.

Tabel 2. Jumlah Sampel Petani Responden Berdasarkan Lokasi Kecamatan dalam Program SL-PTT Kedelai di Kabupaten Ciamis 2013

\begin{tabular}{lcccc}
\hline \multirow{2}{*}{ Kecamatan } & \multicolumn{2}{c}{ Anggota Populasi } & \multicolumn{2}{c}{ Jumlah Sampel } \\
\cline { 2 - 5 } & Lahan Sawah & Lahan Darat & Lahan Sawah & Lahan Darat \\
\hline Rancah & 736 & 587 & 42 & 34 \\
Kawali & 456 & 213 & 26 & 12 \\
Ciamis & 598 & - & 34 & - \\
Sindangkasih & 230 & 462 & 13 & 26 \\
Panjalu & 697 & - & 40 & - \\
Cihaurbeuti & - & 1.152 & - & 65 \\
Purwadadi & 1.539 & - & 87 & - \\
\hline Jumlah & 4.256 & 2.414 & 241 & 137 \\
\hline
\end{tabular}

Selanjutnya dari masing-masing jenis lahan baik lahan sawah maupun lahan darat distratifikasikan berdasarkan rata-rata luas lahan dari masing-masing jenis lahan menjadi lahan luas dan lahan sempit.

\section{Rancangan Analisis Data dan Uji Hipotesis}

Pengukuran indikator karakteristik dan perilaku petani kedelai, dibagi kedalam lima kategori dengan panjang kelas interval untuk setiap kategori dihitung menurut (Sudjana, 2002) :

Panjang kelas interval $=\frac{\text { Rentang }}{\text { Banyaknya Kelas }}$ atau $\mathrm{I}=\frac{\text { Nilai Tertinggi }(\mathrm{NT})-\text { Nilai Terendah }(\mathrm{NR})}{\sum \text { Kategori }}$ 


\section{AIMBAR \\ Agribisnis}

ISSN 2460-4321

Volume 1・ Nomor 2・ Januari 2016

Untuk menguji hipotesis yang diajukan mengenai hubungan karakteristik petani dengan perilaku dalam melaksanakan usahatani kedelai sistem PTT, digunakan Korelasi Rank Spearman (Spearman Rank Correlation) dengan rumus (Sugiyono, 2005), sebagai berikut :

$r_{s}=1-\frac{6 \sum d_{i^{2}}}{n\left(n^{2}-1\right)}$

Keterangan :

$r^{S}=$ Korelasi Rank Spearman.

$\mathrm{d}_{1}^{2}=$ Perbedaan antara jumlah rank $\mathrm{X}$ (nilai dari karakteristik petani kedelai) dan rank Y (nilai dari perilaku petani dalam melaksanakan usahatani kedelai sistem PTT).

$\mathrm{n} \quad$ = Banyaknya pasangan data atau jumlah responden.

Untuk pengujian hipotesisnya digunakan uji t dengan rumus sebagai berikut:

$$
\mathrm{T}_{\text {hitung }}=r_{s} \sqrt{\frac{\mathrm{N}-2}{1-\left(\mathrm{r}_{\mathrm{s}}\right)^{2}}}
$$

Jika terdapat rank kembar dari variabel tersebut, masing-masing diberi rank rata-rata sehingga pengaruh rank kembar dapat diatasi. Untuk menghitung korelasi apabila terjadi rank kembar digunakan rumus sebagai berikut :

$$
\mathrm{r}_{\mathrm{s}}=\frac{\sum \mathrm{X}^{2}+\sum \mathrm{Y}^{2}-\sum \mathrm{di}^{2}}{2 \sqrt{\sum \mathrm{X}^{2} * \sum \mathrm{Y}^{2}}}
$$

Keterangan :

$\mathrm{r}_{\mathrm{S}} \quad=$ korelasi Rank spearman

$\sum \mathrm{x}^{2}=$ Nilai dari karakteristik petani

$\sum \mathrm{y}^{2}=$ Nilai dari perilaku petani dalam melaksanakan usahatani kedelai

$\sum \mathrm{d}_{\mathrm{i}}^{2}=$ perbedaan jumlah rank $\mathrm{x}$ dan $\mathrm{y}$
Dimana :

- Tx dan Ty sebagai faktor koreksi

$-\mathrm{T}=\sum \frac{\mathrm{t}^{3}-\mathrm{t}}{12}$

Untuk kepentingan analisis rank spearman digunakan microsoft sofwert SPSS versi 17.

Selanjutnya untuk mengetahui tingkat hubungannya, maka dilakukan pengujian sesuai pendapat Sugiyono (2005) dengan cara perhitungan sampel besar (n lebih besar dari 10). Pengujian hipotesis dilakukan dengan kriteria sebagai berikut :

$\mathrm{t}_{\text {hit }}<\mathrm{t}_{0,05}=$ tidak nyata (non significant)

$\mathrm{t}_{0,05}<\mathrm{t}_{\text {hit }}>\mathrm{t}_{0,01}=$ nyata $($ significant $)$

$\mathrm{t}_{\text {hit }} \geq \mathrm{t}_{0,01} \quad=$ sangat nyata (highly

significant)

\section{HASIL DAN PEMBAHASAN}

Karakteristik Petani Peserta Program Pengembangan SL-PTT Kedelai

Hasil penelitian menunjukkan bahwa karakteristik petani kedelai baik lahan sawah maupun lahan darat secara umum masuk dalam kategori sedang. Hal tersebut menunjukkan bahwa karakteristik petani baik lahan sawah maupun lahan darat memiliki karakteristik yang sama. Karakteristik petani lahan sawah secara umum memiliki nilai rata-rata 30,05 sedangkan petani lahan darat secara umum memiliki nilai rata-rata 34,80 dari skor harapan 65 .

Karakteristik petani kedelai baik di lahan sawah maupun lahan darat memiliki karakteristik yang masuk ke dalam kategori sedang. Untuk lebih jelasnya dapat dilihat pada tabel berikut.

Dengan ketentuan :

$$
\begin{aligned}
\sum \mathrm{x}^{2} & =\frac{\mathrm{N}^{3}-\mathrm{N}}{12}-\sum \mathrm{T} \mathrm{x} ; \\
\sum \mathbf{y}^{\mathbf{2}} & =\frac{\mathbf{N}^{\mathbf{3}}-\mathbf{N}}{\mathbf{1 2}}-\sum \mathbf{T} \mathbf{y} ;
\end{aligned}
$$


Tabel 3. Nilai Rata-rata, Skor Harapan, Nilai Tertimbang (NT) dan Kategori Variabel Karakteristik Petani dalam Penerapan Program SL-PTT Kedelai di Kabupaten Ciamis

\begin{tabular}{|c|c|c|c|c|c|c|c|c|}
\hline \multirow[b]{2}{*}{$\begin{array}{c}\text { Variabel dan Sub } \\
\text { Variabel Karakteristik } \\
\text { Petani }\end{array}$} & \multicolumn{5}{|c|}{ Lahan Sawah } & \multicolumn{3}{|c|}{ Lahan Darat } \\
\hline & $\begin{array}{l}\text { Nilai } \\
\text { Rata- } \\
\text { rata }\end{array}$ & $\begin{array}{c}\text { Skor } \\
\text { Harapan }\end{array}$ & NT $(\%)$ & Kategori & $\begin{array}{l}\text { Nilai } \\
\text { Rata- } \\
\text { rata }\end{array}$ & $\begin{array}{c}\text { Skor } \\
\text { Harapan }\end{array}$ & NT (\%) & Kategori \\
\hline Umur & 3,82 & 5 & 77,00 & Sedang & 2,44 & 5 & 55,20 & Rendah \\
\hline Pendidikan N.Formal & 5,91 & 10 & 59,10 & Sedang & 4,26 & 10 & 45,80 & Rendah \\
\hline Tanggungan Keluarga & 3,77 & 5 & 75,40 & Sedang & 3,38 & 5 & 75,20 & Sedang \\
\hline Luas Lahan & 3,07 & 5 & 61,40 & Sedang & 2,15 & 5 & 49,40 & Rendah \\
\hline Pendapatan & 2,07 & 5 & 41,40 & Rendah & 1,48 & 5 & 32,40 & S. Rendah \\
\hline Kekayaan & 3,63 & 5 & 72,60 & Sedang & 2,69 & 5 & 58,20 & Rendah \\
\hline Pengalaman Usahatani & 1,45 & 5 & 29,00 & S. Rendah & 1,05 & 5 & 21,00 & S. Rendah \\
\hline Akses Informasi & 6,94 & 10 & 69,40 & Tinggi & 6,35 & 10 & 59,07 & Sedang \\
\hline Akses Kelompok & 6,49 & 10 & 64,90 & Sedang & 5,96 & 10 & 65,10 & Sedang \\
\hline Akses Pasar & 1,99 & 5 & 39,8 & S.Rendah & 1,95 & 5 & 43,00 & S.Rendah \\
\hline Jumlah & 39,05 & 65 & 60,08 & Sedang & 34,80 & 65 & 53,54 & Sedang \\
\hline
\end{tabular}

Dilihat secara mendalam dengan mengkalsifikasikan berdasarkan luas lahan, diperoleh nilai karakteristik untuk kategori lahan sempit baik lahan sawah maupun lahan darat dapat dilihat pada Tabael 4.

Tabel 4. Nilai Rata-rata, Skor Harapan, Nilai Tertimbang (NT) dan Kategori Variabel Karakteristik Petani dalam Penerapan Program SL-PTT Kedelai Model Kategori Lahan Sempit di Kabupaten Ciamis

\begin{tabular}{lcccccccc}
\hline \multicolumn{1}{c}{\begin{tabular}{c} 
Variabel dan Sub \\
Variabel Karakteristik \\
\multicolumn{1}{c}{ Petani }
\end{tabular}} & $\begin{array}{c}\text { Nilai } \\
\text { Rata- } \\
\text { rata }\end{array}$ & $\begin{array}{c}\text { Skor } \\
\text { Harapan NT (\%) }\end{array}$ & Kategori & $\begin{array}{c}\text { Nilai } \\
\text { Rata- } \\
\text { rata }\end{array}$ & $\begin{array}{c}\text { Skor } \\
\text { Harapan }\end{array}$ & NT (\%) & Kategori \\
\hline Umur & 3,76 & 5 & 75,20 & Sedang & 2,87 & 5 & 57,40 & Sedang \\
Pendidikan & 4,70 & 10 & 47,00 & Rendah & 3,78 & 10 & 37,80 & Rendah \\
Tanggungan Keluarga & 3,60 & 5 & 72,00 & Sedang & 3,67 & 5 & 36,70 & Sedang \\
Luas Lahan & 2,98 & 5 & 59,60 & Rendah & 2,52 & 5 & 50,40 & Rendah \\
Pendapatan & 1,85 & 5 & 37,00 & S. Rendah & 1,56 & 5 & 31,20 & S. Rendah \\
Kekayaan & 3,39 & 5 & 67,80 & Sedang & 2,63 & 5 & 52,60 & Rendah \\
Pengalaman Usahatani & 1,34 & 5 & 26,80 & S. Rendah & 1,05 & 5 & 21,00 & S. Rendah \\
Akses Informasi & 6,21 & 10 & 62,10 & Sedang & 6,28 & 10 & 62,80 & Sedang \\
Akses Kelompok & 5,70 & 10 & 57,00 & Sedang & 5,51 & 10 & 55,10 & Sedang \\
Akses Pasar & 1,84 & 5 & 36,80 & S.Rendah & 1,88 & 5 & 37,60 & S. Rendah \\
\hline Jumlah & 35,33 & 65 & 54,35 & Sedang & 31,8 & 65 & 48,92 & Rendah \\
\hline
\end{tabular}

Hasil penelitian menunjukkan bahwa dilihat berdasarkan luas lahan degan kategori lahan sempit untuk petanilahan sawah masuk dalam kategori sedang dengan niiah rata-rata yang diperoleh 35,33 . Sedangkan kareakteristik lahan darat memperoleh nilai rata-rata 31,80 dan masuk dalam kategori rendah. Rendahnya karakteristik petani lahan darat ini merupakan alasan kurang tersentuh lahan darat untuk usahatani musiman yang komersial. Sedangkan jika dilihat dari kategori lahan luas maka dapat dilihat pada Tabel 5. 


\section{AIMBAR \\ Agribisnis}

ISSN 2460-4321

Volume $1 ・$ Nomor $2 \cdot$ Januari 2016

Tabel 5. Nilai Rata-rata, Skor Harapan, Nilai Tertimbang (NT) dan Kategori Variabel Karakteristik Petani dalam Penerapan Program SL-PTT Kedelai Kategori Lahan Luas di Kabupaten Ciamis

\begin{tabular}{|c|c|c|c|c|c|c|c|c|}
\hline \multirow[b]{2}{*}{$\begin{array}{c}\text { Variabel dan Sub } \\
\text { Variabel Karakteristik } \\
\text { Petani }\end{array}$} & \multicolumn{5}{|c|}{ Lahan Sawah } & \multicolumn{3}{|c|}{ Lahan Darat } \\
\hline & $\begin{array}{l}\text { Nilai } \\
\text { Rata- } \\
\text { rata }\end{array}$ & $\begin{array}{c}\text { Skor } \\
\text { Harapan }\end{array}$ & NT $(\%)$ & Kategori & $\begin{array}{c}\text { Nilai } \\
\text { Rata- } \\
\text { rata }\end{array}$ & $\begin{array}{c}\text { Skor } \\
\text { Harapan }\end{array}$ & NT $(\%)$ & Kategori \\
\hline Umur & 3,93 & 5 & 78,60 & Sedang & 2,51 & 5 & 50,20 & Rendah \\
\hline Pendidikan & 8,36 & 10 & 83,60 & Tinggi & 6,35 & 10 & 63,50 & Sedang \\
\hline Tanggungan Keluarga & 4,11 & 5 & 82,20 & Tinggi & 3,95 & 5 & 47,40 & Sedang \\
\hline Luas Lahan & 3,29 & 5 & 65,80 & Sedang & 2,37 & 5 & 38,60 & Rendah \\
\hline Pendapatan & 2,50 & 5 & 50,00 & Rendah & 1,74 & 5 & 34,80 & S. Rendah \\
\hline Kekayaan & 4,13 & 5 & 82,60 & Tinggi & 3,53 & 5 & 70,60 & Sedang \\
\hline Pengalaman Usahatani & 1,68 & 5 & 33,60 & S. Rendah & 1,05 & 5 & 21,00 & S. Rendah \\
\hline Akses Informasi & 8,41 & 10 & 84,10 & S. Tinggi & 8,51 & 10 & 85,10 & S. Tinggi \\
\hline Akses Kelompok & 8,10 & 10 & 81,00 & Tinggi & 8,70 & 10 & 87,00 & S. Tinggi \\
\hline Akses Pasar & 2,03 & 5 & 40,60 & Rendah & 2,74 & 5 & 54,80 & Rendah \\
\hline Jumlah & 46,53 & 65 & 71,58 & Tinggi & 41,47 & 65 & 63,80 & Sedang \\
\hline
\end{tabular}

Hasil penelitian meunjukkan bahwa untuk kategori lahan luas karakteristik petani lahan sawah masuk kategori tinggi, sedangkan karaktersitik petani lahan darat masuk dalam kategori sedang. Hal tersebut menunjukkan bahwa semakin luas lahan yang dimiliki petani maka akan semakin tinggi kategori karakteristik yang dimilikinya. Nilai rata-rata yang diperoleh oleh petani lahan sawah adalah 46,53 sedangkan petani lahan darat 41,47 dari skor harapan 65 .

Tingginya krakteristik lahan sawah dibandingkan karakteristik lahan darat merupakan suatu gambaran yang menunjukkan begitu pentingnya kepemilikan lahan sawah dibanding lahan darat berdasarkan sisi sosial dan ekonomi serta budaya dimata masyarakat sekitar daerah penelitian. Sementara karakteristik lahan darat yang berpariasi memberikan suatu gambaran bahwa untuk petani lahan darat memiliki karaktersitik yang berbeda-beda.

\section{Respon Petani Peserta Program Pengembangan SL-PTT Kedelai}

Respon petani yang dimaksud dalam penelitian ini adalah sikap dan perilaku petani dalam melaksanakan kegiatan usahatani kedelai sesuai dengan pedoman Penerapan Program Pengembangan SL-PTT Kedelai di Kabupaten Ciamis. Untuk lebih jelasnya, dapat dilihat sebagai berikut.

Tabel 6. Nilai Rata-rata, Skor Harapan, Nilai Tertimbang (NT) dan Kategori Variabel Respons Petani Kedelai di Lahan Sawah dan Lahan Darat dalam Penerapan Program SL-PTT Kedelai di Kabupaten Ciamis

\begin{tabular}{|c|c|c|c|c|c|c|c|c|}
\hline \multirow[b]{2}{*}{$\begin{array}{c}\text { Variabel dan Sub } \\
\text { Variabel Respons } \\
\text { Petani }\end{array}$} & \multicolumn{5}{|c|}{ Lahan Sawah } & \multicolumn{3}{|c|}{ Lahan Darat } \\
\hline & $\begin{array}{c}\text { Nilai } \\
\text { Rata-rata }\end{array}$ & $\begin{array}{c}\text { Skor } \\
\text { Harapan }\end{array}$ & NT $(\%)$ & Kategori & $\begin{array}{c}\text { Nilai } \\
\text { Rata- } \\
\text { rata }\end{array}$ & $\begin{array}{c}\text { Skor } \\
\text { Harapan }\end{array}$ & NT $(\%)$ & Kategori \\
\hline Pengolahan Lahan & 7,22 & 10 & 73,80 & Tinggi & 7,72 & 10 & 75,2 & Tinggi \\
\hline Varietas Unggul & 11,92 & 15 & 87,00 & Tinggi & 13,50 & 15 & 81,53 & Sangat Tinggi \\
\hline Bersertfikat & & & & & & & & \\
\hline Penanaman & 15,21 & 20 & 82,00 & Tinggi & 16,80 & 20 & 76,15 & Tinggi \\
\hline Pemupukan & 8,60 & 15 & 66,47 & Sedang & 9,81 & 15 & 50,87 & Sedang \\
\hline Mulsa Jerami & 8,56 & 15 & 55,40 & Sedang & 7,73 & 15 & 54,33 & Rendah \\
\hline Pengairan & 9,79 & 15 & 73,60 & Sedang & 11,40 & 15 & 62,67 & Timggi \\
\hline Pengendalian Hama & 11,67 & 20 & 61,10 & Tinggi & 12,62 & 20 & 58,05 & Sedang \\
\hline Pengendalian Penyakit & 11,09 & 20 & 60,40 & Tinggi & 12,40 & 20 & 53,50 & Sedang \\
\hline Panen dan Pasca & 31,80 & 40 & 83,48 & Tinggi & 35,10 & 40 & 83,53 & Sangat tinggi \\
\hline Panen & & & & & & & & \\
\hline Jumlah & 115,90 & 170 & 72,85 & Tinggi & 127,06 & 170 & 68,16 & Tinggi \\
\hline
\end{tabular}


Secara umum dapat dinyatakan bahwa respon petani baik lahan sawah mapun lahan darat masuk dalam kategori tinggi. Hal tersebut dibuktikan dari nilai rata-rata yang diperoleh untuk respon petani lahan sawah 115,90 dan untuk respon petani lahan darat 127,06 dari skor harapan 170. Berdasarkan hal tersebut dapat dinyatakan bahwa petani baik lahan sawah maupun lahan darat dapat merespon program pengembangan SL-PTT kedelai dengan kategori tinggi. Selanjutnya untuk mengerucutkan pembahasan mengenai respon, petani diklasifikasikan berdasarkan luas lahan, yaitu lahan luas dan lahan sempit.

Berdasarkan kategori lahan sempit, dapat dinyatalan bahwa respon petani lahan sawah masuk dalam kategori sedang, sementara petani lahan darat masuk dalam kategori tinggi. Hal tersebut ditunjukkan dengan nilai rata-rata respon petani lahan sawah 103, 06 dan respon petani lahan darat sebesar 117,86. Kategori respon sedang yang diperoleh petani lahan darat dikarenakan petani lahan sawah tersbeut sudah merasa terbiasa dalam melaksanakan usahatani musimam, sementara tinggi kategori respon lahan darat dikarenakan petani merasa senang karena lahan darat yang biasanya digunakan untuk tanaman tahunan bisa lebih intensif dengan keikutsertaanya dalam program pengembangan SL-PTT kedelai di Kabupaten Ciamis. Untuk lebih jelasnya nilai respon petani dengan kategorilahan sempit dapat diihat pada Tabel 7.

Tabel 7. Nilai Rata-rata, Skor Harapan, Nilai Tertimbang (NT) dan Kategori Variabel Respons Petani Kedelai di Lahan Sawah Kategori Lahan di Bawah Rata-rata dalam Penerapan Program SL-PTT Kedelai di Kabupaten Ciamis

\begin{tabular}{lcccccccc}
\hline \multirow{2}{*}{$\begin{array}{c}\text { Variabel dan Sub } \\
\text { Variabel Respons Petani }\end{array}$} & $\begin{array}{c}\text { Lilai } \\
\text { Rata-rata }\end{array}$ & $\begin{array}{c}\text { Skor } \\
\text { Harapan }\end{array}$ & NT $(\%)$ & Kategori & $\begin{array}{c}\text { Nilai } \\
\text { Rata- } \\
\text { rata }\end{array}$ & $\begin{array}{c}\text { Skor } \\
\text { Harapan }\end{array}$ & NT (\%) & Kategori \\
\hline Pengolahan Lahan & 6,29 & 10 & 62,90 & Sedang & 6,89 & 10 & 68,90 & Tinggi \\
Varietas Unggul & 10,50 & 15 & 70,00 & Tinggi & 13,29 & 15 & 88,60 & Sangat \\
Bersertfikat & 13,80 & 20 & 69,00 & Sedang & 15,67 & 20 & 78,35 & Tinggi \\
Penanaman & 7,68 & 15 & 51,20 & Rendah & 9,35 & 15 & 62,33 & Sedang \\
Pemupukan & 8,25 & 15 & 55,00 & Sedang & 7,23 & 15 & 48,20 & Rendah \\
Mulsa Jerami & 8,63 & 15 & 57,53 & Sedang & 10,39 & 15 & 69,27 & Sedang \\
Pengairan & 10,12 & 20 & 50,60 & Rendah & 11,16 & 20 & 55,80 & Sedang \\
Pengendalian Hama & 9,08 & 20 & 45,40 & Rendah & 10,21 & 20 & 51,05 & Sedang \\
Pengendalian Penyakit & 28,68 & 40 & 71,70 & Tinggi & 33,29 & 40 & 83,23 & Tinggi \\
Panen dan Pasca Panen & 103,06 & 170 & 60,94 & Sedang & 117,86 & 170 & 69,33 & Tinggi \\
\hline Jumlah & & & & & & & & \\
\hline
\end{tabular}

Hasil penelitian menunjukkan bahwa respon petani lahan sawah untuk kategori lahan luas masuk dalam kategori tinggi, sedangkan respon petani lahan darat masuk dalam kategori sangat tinggi. Hal tersebut ditunjukkan dengan perolehan nilai rata-rata respon petani lahan darat 141,68 dan nilai ratarata petani lahan darat 147,07 dari skor harapan 170. Hal terebut menunjukkan bahwa respon petani lahan darat lebih baik dibanding respon petani lahan sawah. Untuk lebih jelasnya nilai respon petani dengan kategori lahan luas dapat dilihat pada Tabel 8. 


\section{AIMBAR Agribisnis}

ISSN 2460-4321

Volume $1 \cdot$ Nomor $2 \cdot$ Januari 2016

Tabel 8. Nilai Rata-rata, Skor Harapan, Nilai Tertimbang (NT) dan Kategori Variabel Respons Petani

Kedelai di Lahan Sawah dan Lahan Darat Kategori Lahan di Atas Rata-rata dalam Penerapan Program SL-PTT Kedelai di Kabupaten Ciamis

\begin{tabular}{|c|c|c|c|c|c|c|c|c|}
\hline \multirow[b]{2}{*}{$\begin{array}{c}\text { Variabel dan Sub } \\
\text { Variabel Respons Petani }\end{array}$} & \multicolumn{5}{|c|}{ Lahan Sawah } & \multicolumn{3}{|c|}{ Lahan Darat } \\
\hline & $\begin{array}{c}\text { Nilai } \\
\text { Rata- } \\
\text { rata }\end{array}$ & $\begin{array}{c}\text { Skor } \\
\text { Harapan }\end{array}$ & $\begin{array}{l}\mathrm{NT} \\
(\%)\end{array}$ & Kategori & $\begin{array}{c}\text { Nilai } \\
\text { Rata- } \\
\text { rata }\end{array}$ & $\begin{array}{c}\text { Skor } \\
\text { Harapan }\end{array}$ & $\begin{array}{l}\text { NT } \\
(\%)\end{array}$ & Kategori \\
\hline Pengolahan Lahan & 9,13 & 10 & 91,30 & S. Tinggi & 9,51 & 10 & 95,10 & S. Tinggi \\
\hline Varietas Unggul & 14,78 & 15 & 98,53 & S. Tinggi & 13,95 & 15 & 93,00 & S. Tinggi \\
\hline Bersertfikat & & & & & & & & \\
\hline Penanaman & 18,03 & 20 & 90,15 & S. Tinggi & 19,12 & 20 & 95,60 & S. Tinggi \\
\hline Pemupukan & 10,45 & 15 & 69,67 & Tinggi & 8,74 & 15 & 58,27 & Sedang \\
\hline Mulsa Jerami & 9,20 & 15 & 61,33 & Sedang & 10,98 & 15 & 73,20 & Tinggi \\
\hline Pengairan & 12,15 & 15 & 81,00 & S. Tinggi & 13,60 & 15 & 90,67 & S. Tinggi \\
\hline Pengendalian Hama & 14,81 & 20 & 74,05 & Tinggi & 15,74 & 20 & 78,70 & Tinggi \\
\hline Pengendalian Penyakit & 15,15 & 20 & 75,75 & Tinggi & 16,40 & 20 & 82,00 & Tinggi \\
\hline Panen dan Pasca Panen & 39,53 & 40 & 98,83 & S. Tinggi & 39,02 & 40 & 97,55 & S. Tinggi \\
\hline Jumlah & 141,68 & 170 & 83,34 & Tinggi & 147,07 & 170 & 86,51 & S. TInggi \\
\hline
\end{tabular}

\section{Hubungan Karakteristik dan Respon Petani Peserta Program SL-PTT Kedelai}

Hubungan karakteristik dan respon petani peserta Program SL-PTT kedelai di lahan darat memiliki nilai $r$ sebesar 0,839 dengan signifikansi 0,000 yang lebih kecil dari alpa 0,010. Hal tersebut menyatakan bahwa hubungan karekteristik terhadap respons petani memiliki hubungan yang sangat kuat. Tingginya hubungan tersebut sesuai dengan kenyataan di lapangan bahwa petani lahan darat menghendaki peningkatan pendapatan rumah tangga dalam pemanfaatan lahan darat terutama dalam keikutsertannya dalam program SL-PTT kedelai di Kabupaten Ciamis

Pembahasan mengenai perilaku dan respon petani dalam pelaksanaan Program SL-PTT Kedelai ini, sesuai dengan pendapat Soewardi H (1972) dalam penelitannya yang menyimpulkan bahwa orang-orang yang dinamakan "lapisan atas" (berlahan luas) lebih bersifat responsif terhadap pembaharuanpembaruan.

\section{KESIMPULAN}

Berdasarkan hasil dan pembahasan, maka penelitian ini dapat disimpulkan sebagai berikut:

1. Secara umum karakteristik petani peserta Program SL-PTT Kedelai di Kabupaten Ciamis baik lahan sawah maupun lahan darat masuk dalam kategori sedang. Karakterisrtik petani kategori lahan sempit untuk petani lahan sawah masuk kategori sedang, sedangkan petani lahan darat masuk kategori rendah. Karakteristik petani kategori lahan luas untuk petani lahan sawah masuk kategori tinggi dan petani lahan darat masuk kategori sedang.

2. Respons petani peserta Program SL-PTT Kedelai di Kabupaten Ciamis secara umum masuk kategori tinggi. Respon berdasar kategori lahan sempit untuk lahan sawah masuk kategori sedang dan petani lahan darat masuk kategori tinggi. Untuk kategori lahan luas respon petani lahan sawah masuk kategori tinggi dan petani lahan darat masuk kategori sangat tinggi.

3. Terdapat hubungan karakteristki dan respon petani dalam program pengembangan SLPTT kedelai di Kabupaten Ciamis. Dengan sifat hubungan semakin tinggi karakteristik petani maka semakin tinggi pula respon petani dalam pelaksanaan program SL-PTT kedelai di Kabupaten Ciamis. 


\section{DAFTAR PUSTAKA}

Ajzen Icek dan Martin Fishbein, 1980. Understanding attitudes and Predicting Social Behaviour. N.J : Prantice-Hall Inc, Engglewood Cliffs.

Badan Pusat Statistik. 2010. Jawa Barat dalam Angka. Badan Pusat Statistik Provinsi Jawa Barat. Bandung.

. 2011. Jawa Barat dalam Angka. Badan Pusat Statistik Provinsi Jawa Barat. Bandung.

.2012. Jawa Barat dalam Angka. Badan

Pusat Statistik Provinsi Jawa Barat. Bandung.

Budiman, Arif. 2000. Teori Pembangunan Dunia Ketiga. Gramedia Pustaka Utama. Jakarta

Bungin B. 2013. Metode Penellitan Sosial Ekonomi. Format-format Kuantitatif dan Kualitatif untuk Studi Sosiologi, Kebijakan Publik, Komunikasi, Manajemen dan Pemasaran. Kencana. Jakarta

Dinas Pertanian Tanaman Pangan. 2011. Laporan Tahunan. Dinas Pertanian Tanaman Pangan Kabupaten Ciamis. Ciamis

2012. Laporan Tahunan. Dinas Pertanian Tanaman Pangan Kabupaten Ciamis. Ciamis

2012. Laporan Tahunan. Dinas Pertanian Tanaman Pangan Kabupaten Ciamis. Ciamis

Gibson Ivancevic Donnelly. 2004. Organisasi: Perilaku, Struktur, Proses. Jilid 1. Bina Rupa. Jakarta.

Gerungan. 2004. Psikologi Sosial. Rafika Aditama. Bandung

Hawkins et all. 1986. Penyuluhan Pertanian. Kanasius. Jakarta.

Hilman, dkk. 2005. Dinamika dan Antisipasi Pengembangan Tanaman Pangan Prosiding "Perspektif Pengembangan Pertanian dan Kehutanan Tahun $2001 \mathrm{Ke}$ depan" Buku 1 Puslitbangtan Sosek Pertanian. Bogor.

Kaplan, R.S., \& Norton D.P. 1996. Using The Balanced Scorecard as a Strategic

Kementrian Pertanian Republik Indonesia. 2013. Pengembangan Sektor Pertanian dalam Hegemoni Globalisasi dan Liberalisasi. Disampaikan pada Seminar Nasional dan Mukernas POPMASEPI. Universitas Padjadjaran. Bandung.
Kusrini. 2006. Sistem Pakar - Teori dan Aplikasi. Andi Offset. Yogyakarta.

Lioanan Berger. 1960. Communication Srategies. Illionois the Interstate Printers and Publiher.

Mardikanto T. 1993. Penyuluhan Pembangunan Pertanian. Sebelas Maret Press. Surakarta.

Marwoto dan Hilman. 2005. Prospek dan Pengembangan Agribisnis Kedelai. Badan Litbang Pertanian. Departemen Pertanian. Jakart Grafindo. Jakarta

Mosher, A.T. 1975. Menggerakan dan Membangun Pertanian. Yasaguna. Jakarta.

Nachrowi dan Usman. 2006. Pendekatan Populer dan Praktis Ekonometrika untuk Analisis Ekonomi dan Keuangan, Lembaga Penerbit Universitas Indonesia, Jakarta

Nasution. 2007. Ilmu Komunikasi Sebagai Pengantar. PT. Remaja Rosda Karya. Jakarta

Nazir M. 1988. Metode Penelitian. Ghalia Indonesia. Jakarta

Riduan. 2005. Metode \& Teknik Menyusun Proposal Penelitian. Alfabeta. Jakarta

Saragih, B. 2001. Kumpulan Pemikiran Agribisnis Paradigma Baru Pembangunan Ekonomi Berbasis Pertanian. Pustaka Wirausaha Muda. Bogor.

Sjarkowi dan Sufri. 2004. Manajemen Agribisnis. CV. Baldal Grafiti Press. Palembang

Soekartawi, 1998. Prinsip Dasar Komunikasi Pertanian. Universitas Jakarta Press. Jakarta.

Soewardi H. 1972. Respons Masyarakat Desa Terhadap Modernisasi Produksi Pertanian, Terutama Padi. Disertasi Universitas Negeri Padjadjaran Bandung. Bandung

Sudjana. 2000. Metode Statistika. Tarsito. Bandung

Sugiyono. 2005. Statistika untuk Penelitian. Alfabeta. Jakarta

Sutarto. 2008. Hubungan Sosial Ekonomi Petani dengan Tingkat Adopsi Inovasi Komoditas Jagung di Sidoharjo Wonogir. Jurnal Agritexts No 24 Desember, 2008.

Zakaria A. 2010. Program Pengembangan Kedelai Dalam Peningkatan Produksi dan Pendapatan Petani. Pusat Analisis Sosial Ekonomi dan Kebijakan Pertanian. Kementrian Pertanian. Jakarta. 


\section{AIMBAR Agribisnis}

ISSN 2460-4321

Volume 1・Nomor 2・Januari 2016 